\title{
EMIL LEDERER: BUSINESS CYCLES, CRISES, AND GROWTH
}

\author{
$\mathrm{BY}$
}

\author{
ELISABETH ALLGOEWER
}

\section{INTRODUCTION}

Emil Lederer (1882-1939) was exposed to diverse influences. In Vienna he was a student of Eugen von Böhm-Bawerk, Friedrich von Wieser, and Eugen von Philippovich, but "... when Hilferding and Otto Bauer spoke in those Viennese seminars Lederer must often have taken the side of the Marxists" believe Jakob Marschak et al. (1941, p. 80). ${ }^{1}$ In Berlin, Lederer attended Gustav Schmoller's lectures. His supervisor in Munich, where he received a second doctoral degree, was Lujo Brentano. Lederer's habilitation submitted to the University of Heidelberg entailed "the first comprehensive analysis of the working conditions and political attitudes of salaried employees" (Dickler 1987, p. 157). As much as his last work, on the State of the Masses, published posthumously in 1940, it was an important contribution to sociology. ${ }^{2}$

Lederer's work in economics reflects this rich background. On the one hand, there are roots in the German historical school with its holistic approach to economic and social phenomena, but also its meticulous empirical investigations, detailed collection, and examination of facts. On the other hand Lederer's roots are in the Austrian school, stressing theoretical analysis and deductive reasoning. His theoretical interests go far beyond the neoclassical tradition and extend to Marxist and classical-Ricardian theory.

Graduate Institute of International Studies, Geneva, and University of St. Gallen, Dufourstrasse 48, CH-9000 St. Gallen, Switzerland. I would like to thank an anonymous referee for detailed comments and suggestions and Perry Mehrling and participants of a workshop at the History of Economics Society meetings in June 2001 for the discussion of an earlier version of the paper. The usual caveat applies.

${ }^{1}$ Joseph A. Schumpeter was another fellow-student and an important influence, as can be seen especially in Lederer's early business cycle theory. De Vecchi (1995, pp. 164-65) discusses Lederer's influence on Schumpeter concerning the concept of "rationalization of life" in modern capitalist societies. He also points out that despite their differing political positions, Lederer and Schumpeter shared opinions on several aspects of economic policies concerning the reconstruction of the Austrian and German economies post-World War I despite their differing political positions (de Vecchi 1995, p. 97 fn. 25 and p. 132).

${ }^{2}$ Marschak, et al. (1941) give an overview and appreciation of Lederer's life-work as economist, Lasker et al. (1940) discuss Lederer as sociologist. For biographical information see Dickler (1987, p. 157), Esslinger (1999, pp. 354-55), and Hagemann (2000, pp. 26-28).

ISSN 1042-7716 print; ISSN 1469-9656 online/03/030327-22 @ 2003 The History of Economics Society DOI: $10.1080 / 1042771032000114755$ 
Examples of those roots in quite different camps can be found in the literature Lederer cites in his 1925 article on business cycles: Karl Marx and Rosa Luxemburg are listed side by side with Joseph A. Schumpeter, Knut Wicksell, and Gustav Cassel. Authors whose writings are not published in German are mentioned as well; besides Albert Aftalion and others, special emphasis is given to the "English and American literature" with John A. Hobson, Thorstein Veblen, A. C. Pigou, Wesley C. Mitchell, Irving Fisher, and John Maynard Keynes (Lederer 1925, p. 355). In Aufriss der ökonomischen Theorie (1931a) Lederer discusses the labor theory of value and the marginalist price theory both extensively and critically, and points out the virtues and uses of each.

To sum up, Lederer's work combines approaches that were at other times the subject of fierce professional debates and which are often - to this day-presented as irreconcilable. Therefore it is impossible to fit Lederer into any one school of thought; he does not conform to expected patterns. In his writings he comes off as a fascinating, if idiosyncratic, thinker. He was a versatile writer. Besides addressing his fellow academics he contributed to newspapers and journals aimed at a non-academic audience.

Here I focus on Lederer's contributions to business cycle analysis, which are a prime illustration of his diverse background. Dickler (1981, p. 267) argues that Lederer combines "central ideas of classical political economy and Marx's theory of accumulation" with "Schumpeter's ideas on innovation and credit." 3 Lederer supports his theoretical arguments with empirical data, discussions of institutions, and references to recent developments. Therefore, these contributions also exemplify how Lederer links theoretical reasoning and empirical work.

This paper traces the development of Lederer's business cycle, crisis, and growth analysis. The first section discusses the explanation put forward in 1925 in "Konjunktur und Krisen" (Grundriss der Sozialökonomie). In the second section, two further works are analyzed that can be understood as extensions of the analysis presented in 1925. In his article of 1927, "Monopole und Konjunktur," Lederer expands an aspect already mentioned in 1925. In Technical progress and unemployment (1931b), which was revised and extended for the International Labour Office's Studies and Reports series (1938) Lederer analyzes crises in the context of labor-saving technical progress. In section III, the reception of Lederer's contributions is discussed. Among other aspects addressed are the dramatic change in Lederer's research environment through emigration and the shift in macroeconomic analysis brought about by Keynes's General Theory.

\section{LEDERER'S BUSINESS CYCLE EXPLANATION OF 1925 IN "KONJUNKTUR UND KRISEN"}

Lederer builds on a distinction between consumer goods, i.e., goods for final consumption, and investment or producer goods. For an analysis of the circular flow within the economy Lederer (1925, p. 368) extends the Marxian schemes of reproduction to include six social groups, according to their different economic

\footnotetext{
${ }^{3}$ All translations are mine.
} 
functions: There are entrepreneurs and workers in the industrial sector, and there are farmers and agricultural workers. They produce output and thus create income. To these four, Lederer adds groups five and six-public employees and of rentiers, respectively. In contrast to the former four, these latter groups receive their incomes as transfers from the productive sectors. Most importantly their incomes are fixed in long-term contracts, i.e., they do not fluctuate in nominal terms during the business cycle as do profits and wages. ${ }^{4}$

Lederer (1925, pp. 371-76) takes a lot of care to bring out the distinction between disturbances in the circular flow and phenomena of the business cycle. Disturbances in the circular flow are inconsistencies between supply and demand for individual goods or for the output of the consumer and producer goods sectors respectively. They result from misjudgements of demand developments by producers, from good or bad harvests, etc. They do not lead to crises though: price adjustments induce a redistribution of purchasing power between income groups and a redirection of demand. Capacity reserves and stocks of goods allow the supply side to adjust to such disturbances. In other words, Say's law of markets is at work. ${ }^{5}$

Such disturbances in the circular flow cannot explain periodic crises, however; for this Lederer turns to the explanation of cyclical phenomena. A descriptive analysis of the business cycle is followed by a discussion of its causes and of possible remedies, and that is where we turn next. The depression, which Lederer describes as a "static state" (1925, p. 361), is overcome through an increase in effective demand. As a consequence of this impulse, prices increase. This is made possible by an increase in the velocity of circulation and more importantly by "additional credit" as distinct from a mere transfer of savings. It is additional credit that makes a boom possible: savings are invested in all phases of the cycle. ${ }^{6}$ Money and credit are thus essential although monetary factors are not seen as initiating the cycle. To the extent that stocks and spare capacity are available, output will begin to rise as well. Prices do not increase evenly across all sectors of the economy: less competitive industries, especially in primary goods production, will experience larger price increases than competitive industries in final goods. Wages will rise more slowly than prices, as wage contracts usually cover longer terms. Lederer supports this argument by the empirical observation that profits

\footnotetext{
${ }^{4}$ The position of shareholders is somewhere in between: Lederer $(1925$, p. 401$)$ expects dividends to rise less than profits in the boom.

${ }^{5}$ Lederer (1925, p. 374) qualifies this statement in an argument reminiscent of Clower's dual-decisionhypothesis: in the case of an exceptionally good harvest with a significant fall in agricultural prices, the income losses of the agricultural population may not be compensated by the increases in their customers' purchasing power. The reduced demand from the agricultural sector as a result of reduced income may lead to a general crisis. Lederer insists that this is not the normal course of events; usually equilibrium is restored by market forces.

${ }^{6}$ As interest rates increase with an increased demand for credit, a selection of the most profitable production possibilities takes place. This positive effect is potentially overruled by a problem inherent in a fragmented competitive banking system: too large a proportion of credits could flow into seemingly promising industries. Lederer $(1925$, p. 384$)$ argues that this danger will be reduced as the "self-organization" of the capitalist economy increases: the more concentrated the banking industry and thus the granting of credit is, "... the more reason to expect an appropriate allotment of additional credit."
} 
rise in this phase of the business cycle. To make the increase possible, at least one cost component must increase less than prices. If goods prices rise in all sectors, even if to varying degrees, it is necessary that wages grow more slowly to allow profits to rise across the economy.

As a result, the increase in the wage bill will lag behind the increase in the value of production. The share of wages in the social product will fall, and the share of profits will increase. Since Lederer $(1925$, p. 393) assumes that wages are predominantly spent on consumption and profits are predominantly invested, this implies an alteration in the composition of demand. With rising profits and accumulation, demand for producer goods rises, whereas demand for final products lags behind. ${ }^{7}$ Investment goods industries grow faster than consumer goods production. The unbalanced growth reflects the uneven development of different types of income though. Therefore such disproportions are fundamentally different from the disproportions discussed above. The former result from unexpected changes in supply or demand, implying an allocation not corresponding to purchasing power. Here, in contrast, it is purchasing power that directs the development into disproportion. From the perspective of firms, the allocation is optimal (Lederer 1925, p. 394). That it is unsustainable from a macroeconomic perspective though will become obvious towards the end of the boom.

The disproportional development of incomes implies that the capacities built up in producer goods industries are excessive. The demand for consumption goods is inadequate in the sense that it does not call for an extension of the production facilities in this sector, an extension that would be imperative to keep up the demand for investment goods. This "discrepancy between the development of production and income" (Lederer 1925, p. 386) underlies the upper turning point of the cycle. Although the income development, and thus the differential increase in demand, has driven accumulation, the build-up in investment goods industries has been too fast. Under these circumstances the "realization of profits" is not possible for all investments (Lederer 1925, p. 394). This will reduce spending. Demand begins to fall off, goods remain unsold. The downturn begins with "uncertainty in the market" (Lederer 1925, p. 363), usually in conjunction with a credit contraction. As interest rates rise, costs increase for those firms who relied on credit financing for their additional investment.

Lederer points out that the reduction in demand may first appear in any sector of the economy, although he concedes that in recent cycles the crises first emerged in heavy industries. Where the reduction in demand is felt first does not influence the course of events. ${ }^{8}$ The effects will be carried from firm to firm as demand is curtailed, prices and profits fall, output is reduced, and capital values have to be adjusted. ${ }^{9}$ The crisis is the prelude to depression, the economy returns to a static state without new investment. During the depression, income shares are reverted

\footnotetext{
${ }^{7}$ This process is supported by forced saving, which results not only from the slow adjustment of wages but also from fixed incomes of public employees and rentiers (Lederer 1925, p. 383).

${ }^{8}$ The same is true for the increases in demand that start the boom.

${ }^{9}$ Lederer $(1925$, p. 367$)$ points out that rising prices in the boom and falling prices in the depression cause consumers to behave procyclically. In the boom they increase their stocks to avoid further price increases. Once prices begin to fall in the downturn they postpone purchases in order to benefit from falling prices.
} 
as prices fall faster than wages. Profits are reduced and the purchasing power of wages and, in particular of fixed incomes, is increased. This is reflected in the composition of aggregate demand; production adjusts accordingly.

Lederer (1925, p. 390) allows for exogenous causes of business cycles, he mentions increased export demand, e.g., from a country introducing a railway system or importing war materials. But more importantly, he describes the business cycle as an endogenous movement of a growing economy that does not need any impulses from outside (Lederer 1925, p. 403). In the depression the increased purchasing power of fixed-income recipients stabilizes demand, depletes stocks, and leads to an increase in production, starting the upswing. In much the same way the reduction in purchasing power of this part of national income during the boom eventually leads to a downturn and to depression. Price movements are a necessary part of the business cycle. They induce the uneven development of income streams, which cause the fluctuations in economic activity. Here the importance of Lederer's extension of the Marxian reproduction schemes becomes clear: the added groups of fixed income recipients are central to his business cycle explanation. As much in the boom as in the depression, fixed incomes act as stabilizers of disproportional developments. ${ }^{10}$

The business cycle is seen as an integral part of the (capitalist) economic process by Lederer (1925, p. 368), who references Schumpeter on this point. Even as the static state of depression is reached at the end of the business cycle and the level of economic activity is reduced as compared to the preceding boom, the social product will have increased from one depression to the next (Lederer 1925, p. 383). From his analysis Lederer (1925, p. 413) concludes that cyclical fluctuations in economic activity could only be avoided in a planned economy. A continuous and even expansion of the production capacity and the adjustment to changed demands and technological possibilities would require planning.

Exactly what Lederer envisions when he suggests planning is not addressed in his contribution on business cycles in 1925. Conceptions of a planned economy are discussed in detail in his 1932 book. Lederer contends that "Every planned economy must aim for entirety - it includes an aspect of totality as everything is

\footnotetext{
${ }^{10}$ Fixed income recipients are central to Tugan-Baranovsky's explanation of the "industrial cycle" in his study of industrial crises in England (Tugan-Baranovsky 1901, pp. 232-54). Tugan was the first author to develop a business cycle theory from Marx's reproduction analysis. Although Lederer builds on this aspect of Tugan's writings (Lederer cites him in the literature list and mentions him in his notes on the history of business cycle explanations), their theories are fundamentally different. Lederer's business cycle is driven by demand: consumption spending out of fixed incomes stabilizes the economy in the depression and eventually leads to recovery. In Tugan the importance of fixed incomes lies in the continuous provision of savings during the business cycle. In the depression this leads to an accumulation of loanable funds; these will eventually induce renewed investment and thus lead to an expansion. Tugan-Baranovsky illustrates this line of thought by comparing the accumulation of loanable funds with the building up of steam pressure in a steam engine. This argument is explicitly rejected by Lederer who maintains that savings are fully invested in all phases of the business cycle (1925, pp. 377-78, n. 1). Lederer's demand-driven vision of the business cycle contrasts with Tugan's classical view: "It is not consumption that determines production in the capitalist economy, instead it is production that determines consumption" (Tugan-Baranovsky 1901, p. 253).
} 
steered towards a system of production for the purposes of consumption" (1932, p. 35). Nonetheless he argues that "Free and planned economies are opposites only in principle, but they do not exclude each other in reality" $(1932$, p. 9). $\mathrm{He}$ discusses the possibility of sectors with market coordination in a planned economy and examples of planned sectors in market economies such as water supply, the road system, and the public school system. In short, when Lederer suggests planning as a solution to fluctuations, this does not imply the elimination of markets. Lederer envisions macroeconomic planning to prevent disproportional developments that result from forecasting errors of profit-oriented individual decisions.

In a capitalist system, intertemporal coordination failures are pervasive since individually profit-maximizing firms are incapable of avoiding mistakes provoked by misleading price signals. The ensuing sectoral imbalances are corrected in the disruptions of a crisis, resulting in the destruction of wealth and in unemployment. In a capitalist economy, business cycles are a necessary part of development and growth. Therefore Lederer questions the suggestion of stabilizing the value of money as a remedy for business cycles. He doubts that an economy with monetary stability could grow as fast as an economy with fluctuating value of money: "To achieve fast growth a capitalist economy needs the incentive of extraordinary profit" (Lederer 1925, p. 413).

Considering all of this, it is not surprising that Lederer rejects most contemporary suggestions for stabilizing the economy as either ineffective or undesirable. The crisis is necessary for eliminating the disproportionalities in the production sphere that develop during the boom; the depression has to run its course. Therefore credit creation in the depression would only lead to inflation as long as the necessary adjustments have not taken place (Lederer 1925, p. 406). In theory a redistribution of income from profit to wage recipients could prevent a crisis resulting from the disproportional development of income shares (Lederer 1925, p. 401). However, wage increases in the downturn would be opposed to firms' endeavors to reduce costs and postpone necessary corrections in the production sphere. Moreover, wage increases would run counter to the deflation that is necessary in a depression to reverse the inflationary excesses of the boom. However, Lederer $(1925$, p. 403) welcomes trade unions' resistance to wage reductions in the depression, as stabilized wages will help stabilize demand for consumption goods. ${ }^{11}$ This is also the effect of public works and other support for the unemployed, motivated by the aim of alleviating the hardship of workers.

Forms of government spending that go beyond such a limited extent are rejected by Lederer (1925, p. 407). He explicitly mentions bond-financed government spending on war materials. Even though this would allow production and income generation, which would otherwise not take place during the crisis, it is undesirable. Lederer's case does not rest on Ricardian equivalence though. Assuming government spending to be consumptive, he argues with the growth effects of reduced investment: the placement of government bonds absorbs

\footnotetext{
${ }^{11}$ Wages need to fall in the depression, but they should fall less rapidly than prices. Otherwise the crisis will be deepened.
} 
savings at the time of issue. Tax-financed debt services again employ savings. In other words, Lederer assumes that taxes primarily reduce savings and private investment, and not consumption as a Keynesian consumption function view would suggest. Lederer thus points out the reduction in capital accumulation and growth potential that would result from bond-financed government spending. In sum, although Lederer emphasizes insufficient aggregate demand during the crisis, he does not recommend demand stabilization in a Keynesian manner. Diebolt's (1997, p. 43) interpretation that Keynesian economic policy conclusions follow logically from Lederer's theory must be rejected.

The topic of Lederer's (1927) contribution on business cycles, the effect of cartels, is already briefly discussed in his 1925 article (Lederer 1925, pp. 409-11). Cartels or organized industries deserve attention in the discussion of business cycles as their importance has increased in the last quarter of the nineteenth century. Cartelized industries can protect their profits from the effects of crises by stabilizing prices. But this will lead to transfers of purchasing power from other sectors of the economy and intensify the crisis there. In short, the advantages the organized sector can draw for itself are compensated by disadvantages in other sectors. There are no positive effects for the economy as a whole, and the depression might even be worsened in this case. The next step in Lederer's argument is to ask whether the organization of the entire economy on the basis of cartels could limit the effects of business cycles. Price reductions in the crisis could be precluded by reduced quantities, the fluctuation of profits and of prices would be dampened. But this would foreclose the increase in consumption resulting from the price elasticity of demand, and the impulse for a new upswing would be dampened also. The depression would be prolonged.

Lederer (1925, p. 412) expects the institutionalization of central banks, a process he describes as taking place in Europe and the U.S. at the time, to be the "most effective way" to control and dampen the business cycle. The regulation of overall credit creation on the one hand, an overview over economy-wide lending on the other, would allow the system to avoid the excessive increases in credit creation and the over-financing of seemingly promising sectors that occur in a competitive banking industry. ${ }^{12}$ As mentioned earlier (see n. 6) Lederer expects similar effects from an organized banking industry following its own profit interests. Both developments would introduce an element of macroeconomic planning: information on sectoral growth that individual investors could not obtain would become available to the banks. Credit policy based on this information would allow more realistic appraisals of profitability and could thus help prevent disproportional developments.

Lederer's Austrian heritage is conspicuous in his business cycle explanation, especially in his explicit following of Schumpeter in core areas of the argument and in several references to Schumpeter's work. Among them the following are essential: the central importance of credit in financing the boom, the discussion of disproportional developments in the producer and consumer goods sectors in the course of the business cycle, and the function of crisis and depression in correcting the misallocations of the boom. In both the contemporary Austrian

12 This idea is presented in more detail in Lederer (1932, pp. 16-33). 
and Lederer's writings, unemployment is mentioned only in passing. The disruption that economic growth suffers from the business cycle and not the effects in labor markets is at the center of attention. This change in emphasis in the theoretical literature would have to wait until the overwhelming unemployment of the Great Depression of the 1930s.

The role of monetary factors in Lederer's business cycle analysis can be clarified against the background of Ellis's classifications in German monetary theory 1905-1933 (1934, pp. 315-74). Lederer's argument shares many aspects of the "Schumpeter-Hahn type of cycle theory" as opposed to the "Mises-Hayek analysis of cycles" and the "Other exponents of credit theories" which add to Mises and Hayek's critique of the first group of authors (Ellis 1934, p. 357). Schumpeter and Albert L. Hahn develop theories where business cycles are tightly linked to monetary phenomena. The expansionary phase, though set off by innovative firms, is accompanied by expanded credit. This credit creation is productive in the sense that it is "the most expeditious way of bringing technical advances to economic fruition" (Ellis 1934, p. 316). Cycles are thus seen in an optimistic light as integral part of the growth process. This view is vehemently rejected by their critics, led by Ludwig von Mises and Friedrich A. von Hayek. Ellis argues that in their pessimistic perspective cycles disturb the growth process and are thus a hindrance to development. The incorporation of technical changes would be best achieved in an environment of falling prices corresponding to falling costs of production (Ellis 1934, p. 316). Such circumstances would also allow continuous equilibrium between investment and savings. Schumpeter and Hahn stress that low interest rates bring about a credit expansion and facilitate growth (Ellis 1934, p. 318). In contrast, Mises and Hayek focus on inadequate money and credit supply, emphasizing quantity rather than price (Ellis 1934, p. 338).

Lederer's argument as presented above clearly sides with Schumpeter's and Hahn's outlook. Like them, Lederer underlines the role of low interest rates in facilitating investment during the expansion. He underlines the cyclical character of the growth process in capitalist economies and, again, together with Schumpeter and Hahn, rejects the view that eliminating cycles would enhance longterm growth. Furthermore, Lederer describes the monetary disturbance during the upswing as a matter of inadequate interest rates rather than an inadequate volume of money and credit.

Whereas we have now drawn attention to similarities between Lederer and some of the Austrian writers (in contrast to others among them), we now turn to aspects where Lederer's views are opposed to a shared position of the Austrian authors. Schumpeter's upswing begins with the appearance of entrepreneurs implementing innovations. In the over-investment theories of Mises and Hayek a misconceived interest rate policy induces firms to invest in more roundabout methods of production. In both branches of Austrian business cycle explanations the impulse for the expansion comes from the supply side. It is firms that act. In Lederer, firms react: they perceive an increase in effective demand and expand their activities accordingly. The same is true for the beginning of the crisis: in Lederer insufficient demand leads to a reduction in supply, whereas in the Austrian authors supply conditions change with the increase in interest rates and set off the contraction in the production sphere. 
There is another central issue where Lederer diverges from the Austrians: he does not develop a concept of intertemporal equilibrium with coinciding natural and market interest rates. Whereas in Austrian theories an intertemporal equilibrium describes an allocation in congruence with time preferences and production possibilities in the economy, there is no corresponding equilibrium concept in Lederer. He does not discuss explicitly what defines the appropriate proportions in the production sphere and the corresponding income shares to be restored in crisis and depression. Considering Lederer's later writings, especially on technological unemployment, it can be assumed though that production technology provides these conditions. If production processes are seen as relatively inflexible concerning the input of labor and capital at any point in time, and if technology is presumed to be fairly unresponsive to relative factor prices but mostly exogenous, then the growth path is defined in real terms for both income shares and corresponding sectoral developments. Lederer's rejection of wage increases or credit-financed public spending to prevent a crisis and prolong the boom by creating demand can be explained with this background. Furthermore, Lederer's discussion of the effects of these measures emphasizes their impact on long-term growth perspectives, a theme that will gain in importance in his later work.

\section{EXTENSIONS}

\section{Monopolies (1927)}

In his 1927 contribution to business cycle theory, Lederer discusses the effects of cartels and trusts on the business cycle. He uses the distinction between static and dynamic analysis, a distinction that would receive more attention in his later work (1931a, 1931b, 1938). Here, Lederer (1927, p. 20) describes a static vision of the economy ("statisches Bild der Wirtschaft") as including both the cases of a static or stationary and an evenly progressing economy ("harmonisch fortschreitende Wirtschaft"). ${ }^{13}$ In a dynamic context "development changes all data incessantly and in fact unevenly" (Lederer 1927, p. 20). Technical progress leads to growth and is necessarily linked to fluctuations, an insight we have already encountered in Lederer's 1925 article as discussed above.

The analysis of cartels and trusts under static conditions builds on an elaboration of the arguments first made by Lederer in 1925 (as discussed above). It leads him (1927, p. 16) to state a paradox: monopolies achieve above-average profits by reducing output below competitive levels. At the same time these high profits are an incentive for additional investment, which would increase future output and potentially undermine the above average profitability. "Whenever

\footnotetext{
${ }^{13}$ In his later writings the "evenly progressing economy" is subsumed under dynamic analysis (Lederer 1931a, p. 97); see the discussion below. The distinction reflects Cassel's in Theoretische Sozialökonomie though he uses slightly different terms (Cassel 1919, p. 23) on "Die stationäre Wirtschaft" (pp. 27-29), on "Die gleichmässig fortschreitende Wirtschaft," and (p. 455) where Cassel argues "Auf diesem Wege führt das Studium der Konjunkturen zu einer Dynamik der Volkswirtschaft, die der früheren Behandlung des Wirtschaftslebens als einer stillstehenden Erscheinung oder als einer gleichförmigen Entwicklung als unerlässliche Ergänzung dienen soll.”
} 
increased profits accrue continuously and are accumulated continuously, an increase in production and consumption, moreover an accelerated increase in consumption, will have to follow if the destruction of the value of the accumulated capital is to be avoided" (Lederer 1927, pp. 16-17). This paradox continues to exist in dynamic conditions, but the extent of contradiction varies in the course of the business cycle. In the boom period high profits allow investments to keep pace with the growth in demand, and accumulation is possible without recourse to the credit market. If several industries in the economy are monopolized this may lead to accelerated growth in the upswing and an earlier crisis than under competitive conditions. In the depression the effect of monopolies is to slow down the adjustment processes. As prices do not fall as fast and to the same extent as in competitive industries, the depression is prolonged. The overall effect of cartelization on the business cycle is thus negative, a conclusion Lederer had already reached in his 1925 article.

Lederer considers basic industries to be highly organized. ${ }^{14} \mathrm{He}$ argues that a return to competitive conditions in these sectors is unlikely given modern production technology. Because of enormous fixed costs, large-scale production is advantageous. Under such technical conditions business cycles become "ever more dangerous" (Lederer 1927, p. 32) from a firm's perspective, as flexibility in adjusting production is lost. "No doubt this so far little considered effect of technical progress is one of the main reasons for the conspicuous enthusiasm of practical men for stabilizing the business cycle if possible" (Lederer 1927, p. 27). From his discussion of the effects of monopolies Lederer concludes that stabilization would only be possible in a planned economy. Regulation through credit policy - which Lederer had seen as an important means to control and dampen fluctuations in his analysis of 1925-is ineffective in monopolized industries that rely predominantly on investment financing from own sources and can therefore circumvent credit markets.

\section{Technical Progress and Unemployment (1931b/1938)}

In the preface to the first edition of Technischer Fortschritt und Arbeitslosigkeit, Lederer (1931b, pp. iv-v) sums up the conclusions of his analysis in plain language. They are far-reaching, rather radical conclusions: Lederer makes technical progress responsible for large-scale and long-term unemployment in the wake of a boom period. Technical progress is "too fast" if the relationship between capital accumulation and population growth does not allow the integration of all workers into the production process, given the new capital-intensive technology. Moreover, the tendency towards cartelization speeds up technical progress and leads to increased unemployment in depressions. Technical progress has "devastating effects," all the more so the more successfully it increases production capacity. Lederer concludes that restraining technical change is a matter of survival for the European nations. In the revised edition published in

\footnotetext{
${ }^{14}$ Concentration and cartelization in basic industries increased considerably in interwar Germany (James 1986, 122-25).
} 
1938 by the International Labor Office, Lederer is much more restrained. To the original title, Technical progress and unemployment, the subtitle An enquiry into the obstacles to economic expansion is added. Lederer extends the analysis substantially (the volume has more than 260 pages, versus 126 pages of the first edition), clarifies his position, and leaves it up to the reader to draw conclusions. The radical rhetoric that surfaces here and there in 1931 has disappeared altogether in the second edition, although the core of the argument is unchanged.

Important developments lie between the two editions of the book. Hitler's assumption of power forced Lederer into emigration. Esslinger (1997) analyzes the influence of these experiences on Lederer's work and argues that familiarity with the economy of the United States changed Lederer's vision of the effects of technical progress. He stresses the abundance and variance in goods supplied and the high degree of mechanization in their production on the one hand, the fabric of American society as differing from the European on the other. Under these impressions the potential of unemployment and waste of resources entailed in labor-saving technical progress seems to have lost some of the threat that is stressed in Lederer's early analysis. As a consequence, the planned economy, offered as a solution to overly rapid technical change in $1931 \mathrm{~b}$, is used only as a benchmark for the evaluation of government policies in a capitalistic economy in 1938 (Esslinger 1997, p. 369).

Apart from the importance of his experiences, Lederer's thinking on the subject of Technical progress and unemployment developed in the intervening years, not least in reaction to the debate that his contribution generated. His first book was clearly meant as a provocation for debate and further analyses of the subject. In the introduction to Technischer Fortschritt und Arbeitslosigkeit, Lederer cautions that his work so far represents only the beginning of "a first attempt at an analysis" and he adds that its "continuation and deepening would be very desirable" (Lederer 1931b, p. iv). Considering the topical nature of Lederer's book in the context of the Great Depression and his far-reaching conclusions concerning economic policy as much as economic theory, it is not surprising that the reactions were resolute. Nicholas Kaldor's scathing review essay, "A Case Against Technical Progress?" was published in Economica in 1932. ${ }^{15}$ In the following year Mentor Bouniatian wrote on "Technical Progress and Unemployment" in the International Labour Review. Both authors build their rejection of Lederer's views on arguments based on neoclassical static equilibrium theory. Central to both articles is the critique of Lederer's vision of technical progress as unrepresentative for technical change in general. Furthermore both authors reject Lederer's pessimism concerning adjustment mechanisms leading the economy back to full employment.

The following discussion focuses on those aspects of Lederer's thinking on technical progress, as presented in the 1938 version of Technical Progress and Unemployment, that are central to our analysis of the development of his business cycle theory. The evolution of his thinking on technical change though worthy of a discussion in its own right, will be considered only in passing. Several detailed discussions that Lederer added in the second edition can be seen as a

${ }^{15}$ Dickler (1981, pp. 287-94) discusses and criticizes Kaldor's review in detail. 
response to the misunderstandings that permeated the reception of the first edition of his book. The clarification concerning the type of technical change that Lederer analyzes is a case in point, as much as his extensive discussion of the nature of dynamic analysis as contrasted with static equilibrium theory. In the second edition of Technical Progress and Unemployment Lederer introduces careful definitions and classifications, uses numerical examples in his argument, branches out into the distinction of various cases under different assumptions, and presents statistical evidence.

It is important to understand that Lederer (1938, p. 22) concentrates on cost saving technical or organizational progress, i.e., rationalization. He distinguishes this type of technical change from innovations that result in additional demand by provoking additional needs and from innovations that lead to the replacement of existing goods and services. ${ }^{16}$ Railroads are his favorite example of the former type of technical changes, the car of the latter. Innovations that result in additional demand are impulses for increased production in the same way as a permanent rise in export demand. Innovations that replace existing products imply a restructuring of production, which may lead to frictions in the adjustment process but not to lasting unemployment. In contrast to both these types of technical progress, rationalization and an increased organic composition of capital are detrimental to growth and lead to large-scale unemployment. This is how Lederer (1938, p. 22) explains the unemployment in the interwar period. ${ }^{17}$ Technical progress in this sense is the topic of Lederer's book.

Building on his earlier work, Lederer (1938, pp. 78-90) stresses the distinction between a static model as a purely theoretical abstraction, a model of the evenly growing economy and a theory of a truly dynamic system. Dynamic conditions that are absent in a static model are introduced by a combination of the following characteristics: the "dynamic psychology on the part of individual economic subjects" (Lederer 1938, p. 86), i.e., their desire to improve living conditions by a growing population, by technical change, and by a flexible monetary system. Without technical change an evenly progressing system can result. But the existing capitalist economy is characterized by technical changes that continuously introduce disruptions. In these circumstances, Lederer rejects the theoretical vision of an economy always tending toward a given equilibrium or equilibrium growth path. Instead, Lederer (1938, p. 92) suggests the analysis of dynamic systems as comprising a tendency that corrects disruptions and prevents the system from falling apart, provided that the volume of production is increasing. These deliberations also imply that "The discussion of the process of growth in

\footnotetext{
${ }^{16}$ Lederer introduces this distinction in his response to Bouniatian's critique in 1933 (pp. 4-7). In his contribution to the Encyclopedia of Social Sciences on "technology," Lederer argues that technological development is the basis for the increased living standards in all parts of society since the industrial revolution. In this article he develops a much broader perspective on technology than in his contributions to economic theory, discussing for example the repercussions of changes in production on society and in politics (Lederer 1934, e.g., p. 556).

${ }^{17}$ Lederer is not alone in interpreting the boom of the $1920 \mathrm{~s}$ as linked to rationalization investment and the following crisis as its result. The issue of whether contemporary unemployment consists of workers made redundant by technical progress is also a central theme of the economists around Adolph Löwe in Kiel (Hagemann 1997, pp. 304, 312).
} 
our capitalist economic system is identical with the discussion of the business cycle in general" (Lederer 1938, p. 92), confirming his approach of 1925.

Lederer analyzes aspects of unemployment, accumulation, and technical progress under simplifying assumptions. First, he discusses the ability of a dynamic system to absorb unemployed workers irrespective of the causes of the unemployment, abstracting from reserves and assuming constant prices. ${ }^{18} \mathrm{He}$ analyzes the cases of increasing and falling returns to scale under the conditions of competitive and monopolistic markets respectively. In all cases he concentrates on the possibility of employing additional workers by investing profits according to current technical conditions. Lederer is interested in the development of "employment capacity" ("Arbeiterfassungsraum" in the German language edition of 1938).

Next, Lederer (1938, pp. 168 ff.) discusses the effects of labor saving technical changes in a specific industry (the dynamic sector) where other sectors continue to apply the original production technology (static sector). He uses numerical examples to follow investment, employment, and output across his model economy. ${ }^{19}$ Unemployment results as primary unemployment in the first round of the introduction of labor saving technology if output is held constant. As capital is drawn from the static sector due to higher profits in the rationalizing sector, production is reduced there: secondary unemployment ensues (Lederer 1938, p. 179).

Lederer discusses the ability of the system to reintegrate these workers. $\mathrm{He}$ rejects the optimism of static analysis that unemployed workers will be easily absorbed as profits and investments increase and wages fall. Crucial to this argument is Lederer's rejection of a concept of "jelly" capital already spelled out in Aufriss der ökonomischen Theorie (1931a, p. 261). Capital, once invested in production processes, cannot be flexibly adjusted to more or less labor-intensive uses. Only new investment conforms to fallen wages, implying a lower capitalto-labor ratio. Therefore wage reductions in the depression cannot eliminate unemployment. They are of limited effect in a macroeconomic perspective. ${ }^{20,21}$ Similarly, Lederer (1938, pp. 214 ff.) argues that "preemptive" wage reductions, i.e., wage reductions with the aim of making labor-saving technical changes unprofitable, are unrealistic. He substantiates this with statistical data on the electric lamp industry, the automobile tire industry, and the United States Postal Service.

The core of Lederer's analysis is the discussion of the ability of the economy

\footnotetext{
${ }^{18}$ Lederer (1938, pp. 93-94) stresses that reserves in all forms-overcapacity, stocks, liquidity, the ability to resort to credit on the side of producers, to money and to permanent consumer goods on the side of consumers - mitigate the effects of disturbances.

${ }^{19}$ Dickler $(1981,1983)$ draws on this analysis when formulating a "Lederer stagnation theorem."

${ }^{20}$ This point is also made in Lederer (1931c) where he substantiates the case with an analysis of the specific conditions in Germany during the Great Depression. Lederer adds other arguments against wage reductions, for a discussion see Hagemann (2000, pp. 36-41).

${ }^{21}$ Diebolt (1997, p. 42) argues that for Lederer "Like for J.M. Keynes, the unemployment persists not because of excessive wage demands but because of the insufficiency of effective demand ..." Insufficient demand is only part of the reason for persistent unemployment in Lederer. More important is the reduction of employment opportunities resulting from labor-saving technical change when capital accumulation is not fast enough, a problem that cannot be cured by wage reductions.
} 
to absorb workers made redundant by labor-saving technical change. Thus he takes up the issues raised in Ricardo's chapter "On machinery," wherein a stationary equilibrium of circular flows is disrupted by the introduction of machinery, reducing the amount of variable capital, i.e., the funds available to pay wages. Lederer traces similar processes in his analysis. He is interested in developments outside an equilibrium growth path, providing what John R. Hicks $(1965$, p. 184; 1973, p. 81) was later to call an analysis of traverse. This approach to issues of growth is quite distinct from what might be called the mainstream of growth theory in the twentieth century. There the possibility of equilibrium growth paths is in the center of attention with questions such as: under what conditions does an economy advance in equilibrium? Is the growth path stable in the sense that deviations generate adjustments that lead the economy back into equilibrium? This fundamental difference distinguishes Lederer's analysis from a Harrod-Domar approach although central tenets are shared-especially the limitational production technology as a source of potentially increasing unemployment. Where Harrod-Domar style growth theory focuses on the conditions of equilibrium growth, Lederer questions the relevance of such analysis. If growth processes are prone to being interrupted by changes that lead not only to temporary deviations from a given path but to changes in the path itself, then the main attention should be directed towards developments initiated by such interruptions. Lederer uses a sectoral approach where he distinguishes static and dynamic sectors. He is interested in changes in relative prices, in factor reallocations due to changed profit conditions, etc. These issues cannot be captured in an aggregate model of the Harrod-Domar type.

The final extension (chapters vi and vii) in Lederer's discussion in Technical Progress and Unemployment is to introduce a modern banking system and thus allow for credit-financed investment. This integrates the present analysis of rationalization investment into Lederer's earlier business cycle theory. By introducing a monetary system investment is not limited by savings (profits) any more. The investment triggered by technical change now initiates a credit expansion and an inflationary boom. Initially unemployment can be avoided: the workers that were laid off as a result of rationalization are integrated into the growing economy. These aspects of Lederer's argument lead Gourvitch (1940, p. 171) to conclude that Lederer's analysis is "closely attached to Schumpeter's because of his emphasis on credit expansion as the method of providing capital for the innovating enterprise, on the ensuing 'race for means of production,' and on the effects of the resulting boom in disguising and deferring the displacement of labor through technological improvements." This disguise of the ultimate effects of labor-saving technical progress is lifted once the reserves of the banking system are exhausted or once firms begin to repay credits out of profits or savings. Investment demand falls; the monetary contraction causes the recessionary impulse to spread through the entire economy. Unemployment results. Again, Lederer stresses that wage reductions will not clear the labor markets. To the reasoning presented above, he now adds the argument that wage reductions will further reduce aggregate demand as workers have less income to spend on consumption. Production will fall as a reaction, aggravating the depression. Labor-saving technical improvements thus deepen business cycle fluctuations (Lederer 1938, p. 250). 


\section{Some appraisals}

The extensions to Lederer's business cycle explanation presented in this section modify his original contribution substantially. The core insight remains untouched though: cyclical fluctuations are an integral part of the growth process in a capitalist system. A separate analysis of either of them is impossible. This also implies that business cycles cannot be understood as fluctuations around a growth trend. Rather, in a capitalist economy growth takes place in conjunction with fluctuations. Only a planned economy can avoid fluctuations and still advance.

Despite this continuity, changes in emphasis in Lederer's consecutive contributions to the analysis of cycles, crises, and growth are discernible. In 1925, Lederer observes and analyzes the interconnection between growth and fluctuations in a somewhat uninvolved way. Suggestions for stabilizing the business cycle are discussed against the background of the theoretical analysis. Most of them are rejected. Lederer does not seem to perceive a particular urgency to mitigate the effects of cycles, although he clearly welcomes means to avoid excesses, e.g., as side effects of the institutionalization of a central banking system. Both extensions to his 1925 business cycle explanation are prompted by what Lederer perceives as recent changes in the capitalist economy. The increased cartelization in industry and the predominance of labor-saving technical change in the post World War I era aggravate business cycles. This adds a sense of urgency to the analysis that is also highlighted by the shift in focus from the effects of cycles on output in his early work to the effects on employment in his later contributions. ${ }^{22}$

The workers made redundant by labor-saving technical change may initially be absorbed into other industries during the upswing. Unemployment is aggravated in the crisis and depression though. The effects of rapid, labor-saving technical change go beyond this: a loss in growth potential results as accumulation lags behind the population development and leaves part of the workforce unemployed. Although the long-term effects of deepened business cycles are not discussed in the context of cartelization, the issue could be raised there also: does the extended depression due to the existence of cartels and trusts lead to losses in terms of the level of the growth process, even though the economy eventually returns to higher activity? In short, issues of path dependence are introduced through the extensions Lederer makes to his business cycle theory. The business cycle no longer just interrupts the growth process; the cause and initial impulse of the cycle, the course, and extent of the depression become crucial for future development.

In 1925 issues of distribution and growth were the center of attention. Dickler (1981, p. 296) therefore claims Lederer as a precursor of Kalecki and Kaldor. In Lederer (1925) the disproportional development of income shares alone could be responsible for endogenous business cycles. As argued above, Lederer focuses

\footnotetext{
${ }^{22}$ Going beyond economic arguments, Lederer's sense of the overall importance of the issues raised by technical change is highlighted in his discussion of the links between the changes in production technology, social organization, and politics as exemplified in his 1934 article, where the emergence of fascist governments is discussed (Lederer 1934, p. 556).
} 
on changes in the composition of demand to explain boom and recession. In his later contributions Lederer concentrates on supply side issues. This is especially true for the analysis of labor-saving technical change, where Lederer traces the effects of technical progress on the development of production capacity and employment.

In this light, the classification of Lederer as underconsumption theorist can be discussed. In Prosperity and Depression (1937/1963, p. 118) Gottfried Haberler lists Lederer, together with John A. Hobson, William T. Foster, and Waddill Catchings, as authors "who have done most in recent times to re-state and propagate the under-consumption theory in a scientific way." Authors in the history of economic thought, if they mention Lederer at all, often present him in the context of underconsumption explanations of the cycle (e.g., Kruse 1959, p. 277; Pribram 1981, p. 377).

Many of the topics concerning underconsumptionists make their appearance in Lederer's writings. This is especially true for his 1925 contribution, wherein Lederer is interested in issues of growth and distribution: the disproportional development of income shares in the upswing and boom lead to an expansion of output capacity that is not matched by the increase in demand. The growth path is not sustainable: a crisis follows. This is a traditional underconsumptionist line of thought where rising income shares of capitalists lead to "over"-saving and "over"-production. A disequilibrium between aggregate supply and demand for consumer goods results. But unlike underconsumptionists, Lederer considers the crisis as necessary to bring about the adjustments in the production sphere. Therefore, Lederer rejects the possibility of preventing a crisis by driving up aggregate demand for final products. Lederer also explicitly rejects the "popular view" that consumption increases the wealth of an economy by increasing circulation. He points out that "The danger of consumption expenditure being too large is usually bigger than the danger of it being too small" (Lederer 1925, p. 379, n. 1). ${ }^{23}$ Savings are desirable as they allow accumulation and growth, a classical concern separating Lederer from underconsumptionists. Lederer does not suggest measures that change the income distribution so as to increase consumption expenditure and reduce savings. What he perceives as central are the decisions over how and where to invest.

The emphasis on the supply side, rather than underconsumptionists' concerns with demand-side issues, is reinforced in Lederer's subsequent contributions to business cycle analysis. In 1927 he argues that cartels and trusts lead to stronger fluctuations because they introduce additional distortions in the allocation of savings and hinder adjustment processes. Again, in his discussion of the effects of technical progress in 1931 and 1938, Lederer concentrates on the supply side. As in his earlier writings, it is not the volume of savings and investment per se that causes problems but the decisions on how and where to invest are crucial:

\footnotetext{
${ }^{23}$ Nevertheless examples of "crude" underconsumption arguments can also be found in Lederer. For example, in his discussion of credit as a means to transfer savings Lederer (1925, p. 379) argues that the possibility of earning interest encourages groups to save who so far had no incentive to do so. This could lead to a discrepancy between production and consumption if everybody reduced consumption and productive capacity were increased by the additional savings. This could lead to excess supply of consumer goods and a collapse of their prices.
} 
they determine the capital intensity of production and the organic composition of capital. The unemployment and decline in growth potential that Lederer analyzes now results from a shift towards more capital-intensive production techniques. Since the economy's savings limit the capital available workers cannot be employed due to a lack in corresponding capital equipment. This is far removed from traditional underconsumptionist concerns. Although technical change also figured in these arguments, the issues raised are completely different: the most important effect of technical change is seen in the increase in the supply of final goods because technical progress increases the output a given amount of savings can produce. Technical progress thus aggravates disequilibria between aggregate supply and demand for final goods. To sum up, although Lederer shares a number of topics with underconsumptionists, his approach and treatment of them is not underconsumptionist.

To return to the evolution of Lederer's thinking on cycles, crises, and growth, attention should be given to the changes in his economic policy conclusions that result from the modifications to his original argument. In 1925 the disproportionalities that are behind cyclical developments result from coordination failures. Macroeconomic planning would avoid them altogether. But Lederer perceives solutions to mitigate cycles also within a purely capitalist economy: a central banking system or an organized banking sector would have the information at its disposal to prevent disproportionalities by adequate credit granting. The discussion of the effects of cartels on business cycles leads Lederer to reject this possibility of controling business cycles, as the investments by cartels and trusts are financed out of their high profits and thus do not depend on bank credit. Influencing income distribution, which he now sees as a means to dampen the effects of the cycle, would require interventionist policies. As already argued in 1925, only a planned economy can escape business cycles altogether and still grow.

Even though Lederer in 1938 abstains from the pointed conclusions of the 1931 version of Technical Progress and Unemployment, the same results must be reached by the reader: labor-saving technical change has grave effects in a market economy. A smooth and fast reintegration of workers as suggested by traditional economic analysis is unlikely. Instead, the absorption will be a long drawn-out process despite wage and price adjustments. If unemployment and the reduction in growth potential is to be avoided, technical change must be curbed. Even though it is not spelled out this brings us back to some form of macroeconomic planning.

\section{CONCLUSION}

In the preceding sections we followed the development of Lederer's business cycle analysis. In his first contribution, the concern with aggregate demand conditions that follow from the income distribution dominates. This brings Lederer close to traditional underconsumption arguments. The distribution between profits and wages determines savings, and savings in turn determine the composition of aggregate demand and thus allocation. During the business 
cycle, different income types grow disproportionally, inducing unsustainable investments. A credit cycle accompanies the fluctuations and allows prices to rise in the upswing and forces them down in the recession. Fixed incomes act as stabilizers in the cycle.

The business cycle is inseparable from growth and development in a capitalist economy. This insight is already present in Lederer's early work but becomes more prominent in his later contributions, especially in his analysis of laborsaving technical change. Technical progress is crucial in its effects on the path of capital accumulation, employment capacity, and output. Lederer focuses on conditions that prevent full employment of labor and thus lead to reduced growth potential. This is far removed from traditional underconsumptionist concerns. The policy implications of Lederer's argument make that clear. As supply side conditions are at the heart of the unemployment problem, it cannot be overcome by demand side measures. Increasing effective demand would not allow the absorption of workers into the production process if accumulation lags behind the growth of the labor supply after technical progress has augmented the organic composition of capital. Therefore, Lederer sees measures of macroeconomic planning to influence the supply side directly as the only way to control the effects of rapid technical progress.

Lederer's business-cycle analysis is remarkable from a methodological point of view. Lederer brings a diverse heritage of theoretical and methodological approaches into his analysis. He is interested in a genuinely dynamic theory of processes of development and growth, of which fluctuations are an integral part. He builds on an analysis of the circular flows of goods and income streams in the economy inspired by Marx's reproduction schemes. But Lederer also includes insights and concepts developed in the framework of equilibrium analysis such as the concept of additional credit or forced savings. In his 1925 and 1927 contributions, Lederer relies on verbal analysis and argument. Although this method still dominates his 1931b/1938 work, he now also uses numerical examples in his reasoning. He constructs cases to follow the development of his model economy through several periods. The underlying assumptions are modified in steps, thus broadening the scope of the analysis. Qualifications are introduced. This, especially, makes his 1938 contribution a demanding read and contrasts with contemporary theoretical work, where a different style of analyzing clear cut - and simplified - theoretical problems is being developed. Lederer does not make the step to generalized formal models, to the modern style of economic theory that was beginning to take hold of the economics profession in Lederer's lifetime. This has to be seen in the context of the kind of problems that Lederer addresses. Traverse analysis does not avail itself to generalized argument to the same extent as equilibrium economics; the ventures of others in this field, especially of Löwe and Hicks, prove this point.

Lederer, although himself not an empirical economist, is keenly interested in the analysis of the phenomena of the business cycle done by his contemporaries. As much in 1925 as in 1938, he presents statistical material to illustrate the problems posed by recent developments and to discuss his theoretical argument. This attempt at integrating deductive theoretical analysis and empirical work may go back to Lederer's student days where he was exposed as much to the 
"theoretical" Austrian as to the "empirical" historical school. Lederer (1925, p. 355) claims that the analysis of economic history is impossible without theory; at the same time his theoretical argument is inspired by and confronted with data. $^{24}$ Therefore, what Löwe (1933, p. 158) praises as a "new alliance between empirical and theoretical analysis" can be found in Lederer's work. His contributions are intriguing because of their topical nature. Lederer is a commentator on contemporary issues, applying rigorous theoretical argument to the pressing problems of his day.

My argument has presented Lederer's work as fascinating. Theoretically, it is rich in providing a synthesis of different traditions. Linking theoretical with institutional and empirical analysis makes it methodologically interesting. Lederer was an acclaimed economist in his day. The question thus arises why Lederer and his work are known to few economists today. The following considerations give hints of an answer.

Schumpeter (1954, p. 884) describes Lederer as "the leading academic socialist of Germany in the 1920's." His reputation is reflected in the prestigious positions he held. A professor at the University of Heidelberg since 1918, he declined offers from the Universities of Leipzig and Frankfurt and it was not until 1931 when he accepted an offer-from the University of Berlin. ${ }^{25}$ "The importance that he had as an economist in the Weimar Republic is not only documented by the appointment to this most important of all economics chairs in Germany, but also by his work for the Archiv für Sozialwissenschaft und Sozialpolitik" (Esslinger 1999, p. 355). This journal, which he edited for several years, was a platform for the reform-oriented economists during the Weimar years but was also open to other traditions (Hagemann 2000, p. 43). Furthermore, Lederer played an active role in the Verein für Sozialpolitik as several of the published protocols of the yearly meetings show. ${ }^{26}$ With the Nazi's assumption of power in 1933, Lederer left Germany. After a short stay in Great Britain he emigrated to the United States. Invited to the New School for Social Research by Alvin Johnson, he became the first dean of the University in Exile and helped to gather a distinguished group of social scientists.

Although Lederer was able to continue his work at an academic institution with little interruption, he was confronted with extraordinary change. A leading economist at the top university in Germany, he came to an institution "under construction" in the United States. He carried much of the construction work himself (see Krohn 1993, pp. 64-66 for details), not least as editor of the newly founded journal Social Research (Esslinger 1999, p. 355). Attracting academically oriented students to the New School was hampered in the early years as the

\footnotetext{
${ }^{24}$ Diebolt (1997, p. 43) describes it as a "paradoxical situation" when Lederer's deductive Austrian tradition is confronted with empirical business cycle analysis. There is no hint, though, that Lederer himself would have found that paradoxical.

${ }^{25}$ Paul A. Baran (professor at Stanford University, 1949-1964) was the only student who finished a doctoral thesis with Lederer during his short tenure in Berlin (Hagemann and Krohn 1999, pp. 25-26).

${ }^{26}$ In Janssen's discussion of the conflict between historical school and theoretical economists in the Verein für Sozialpolitik in the second half of the 1920s, Lederer figures as one of the few established economists in the group of theoreticians (Janssen 1998, pp. 26-38).
} 
Graduate Faculty of the New School received degree-granting rights only in 1941 (Mongiovi 1997, p. 388), two years after Lederer's premature death. Therefore, Lederer's influence via New School students in the United States was limited.

Besides the dramatic effects of emigration on Lederer's life and work, changes in economics itself help explain why his thinking had not more impact and longer-term following. The effects of Keynes's The General Theory and the Keynesian revolution have to be considered here. The framework of analysis that Keynes introduced redefined macroeconomic analysis. A shift of interest from long-term issues of cycles and growth to a short-term analysis of macroeconomic shocks dominated the years immediately after the publication of The General Theory. Even though problems of growth are addressed in Harrod's and Domar's work soon after, the perspective on these issues had changed. An almost complete break with pre-Keynesian analysis took place, pushing long-standing traditions in monetary and real analysis into the background. Lederer and others at the New School gave The General Theory a "lukewarm" reception (Mongiovi 1997, p. 393). In Technical Progress and Unemployment, Lederer continued to use the tools he had developed from foundations in Austrian, Marxian, and neoclassical theory. We can only speculate on how Lederer would have reacted to an academic environment taken over by the "New Economics." Many of the issues he had raised, especially in his earlier work, make their appearance in Keynesian analysis. But we do not know whether Lederer would have eventually found the Keynesian framework adequate to present his own concerns as, e.g., Hansen can be understood as doing (Mehrling 1997, pp. 130-36; pp. 140-46).

The changes in the economics profession in the postwar era go beyond this. Keynesian macroeconomics on the one hand, and rational choice and general equilibrium analysis on the other, led to a mainstream in economics, the establishment of a fairly unified approach as compared to the diversity of the preceding decades. Theory redefined as formal analysis and empirical study delimited as econometrics brought forward a new type of economist. Economists educated in this era no longer needed to be acquainted with different traditions in economic analysis to succeed, whereas this was still a matter of course for the generation of their teachers. Without a broad background in economic theories it is difficult to understand Lederer's contributions and impossible to advance his lines of thought. Later attempts to do so found limited attention for the same reasons (e.g., the contributions to the volume on technical progress and unemployment edited by Hagemann and Kalmbach in 1983).

In sum: the forced emigration and the changes in Lederer's work environment that came with it cut Lederer from his established position of influence and standing. Whereas the tradition he stood for in the Weimar Republic was truncated by Nazi empowerment, the circumstances and the few years he had left in the United States did not allow him to rebuild a similar sphere of influence in his new environment. The predominance of mainstream economics that developed in the postwar years led to a breach with longstanding traditions in economic analysis that could not be fitted into the new framework. Lederer's analysis, together with much of the pre-Keynesian cycle and growth analysis, suffered that fate. Part of the aim of this paper is, therefore, to draw attention to 
Lederer's fascinating and differentiated work. His contributions were topical in the sense that he aimed at explaining contemporary problems and suggesting adequate policies to deal with them. His explanation of unemployment stressing technological factors deserves special attention, as these issues are by no means theoretically solved in a satisfactory way to this day.

\section{REFERENCES}

Bouniatian, Mentor. 1933. "Technical Progress and Unemployment.” International Labour Review 27 (3): $327-48$.

Cassel, Gustav. 1919. Theoretische Sozialökonomie. Leipzig: C. F. Winter.

De Vecchi, Nicolò. 1995. Entrepreneurs, Institutions and Economic Change: The Economic Thought of J. A. Schumpeter (1905-1925). Aldershot: Edward Elgar.

Dickler, Robert A. 1981. "Emil Lederer und die moderne Theorie des wirtschaftlichen Wachstums." Nachwort zu Emil Lederer: Technischer Fortschritt und Arbeitslosigkeit. Eine Untersuchung der Hindernisse des ökonomischen Wachstums. Frankfurt am Main: Europäische Verlagsanstalt, pp. 263-327.

Dickler, Robert A. 1983. "Lederer's Theorie der strukturellen Arbeitslosigkeit und lange Wellen." In Harald Hagemann and Peter Kalmbach, eds., Technischer Fortschritt und Arbeitslosigkeit. Frankfurt am Main: Campus Verlag, pp. 186-203.

—. 1987. "Lederer, Emil." In Eatwell, John, Murray Milgate, and Peter Newman, eds., The New Palgrave: A Dictionary of Economics, Vol. III. London: Macmillan, pp. 157-58.

Diebolt, Claude. 1997. "La théorie de la sous-consommation du cycle des affaires de Emil Lederer." Economie Appliquée 50 (1): 27-50.

Ellis, Howard S. 1934. German Monetary Theory 1905-1933. Cambridge, MA: Harvard University Press.

Esslinger, Hans Ulrich. 1997. "Einflüsse der Emigrationserfahrung auf Emil Lederers wirtschaftstheoretische und soziologische Arbeiten." In Harald Hagemann, ed., Zur deutschsprachigen wirtschaftswissenschaftlichen Emigration nach 1933. Marburg: Metropolis Verlag, pp. 353-381.

—. 1999. "Lederer, Emil Hans." In Harald Hagemann and Claus-Dieter Krohn, eds., Biographisches Handbuch der deutschsprachigen wirtschaftswissenschaftlichen Emigration nach 1933. München: Saur, pp. 354-62.

Gourvitch, Alexander. 1940. Survey of Economic Theory on Technological Change and Employment. New York: Augustus M. Kelley, 1960.

Haberler, Gottfried. 1937. Prosperity and Depression. New York: Atheneum, 1963.

Hagemann, Harald. 1997. "Zerstörung eines innovativen Forschungszentrums und Emigrationsgewinn. Zur Rolle der "Kieler Schule" 1926-1933 und ihrer Wirkung im Exil." In Harald Hagemann, ed., Zur deutschsprachigen wirtschaftswissenschaftlichen Emigration nach 1933. Marburg: Metropolis Verlag, pp. 293-341.

- 2000. "Emil Lederer (1882-1939): Economical and sociological analyst and critic of capitalist development." In Peter Koslowski, ed., The Theory of Capitalism in the German Economic Tradition: Historism, Ordo-Liberalism, Critical Theory, Solidarism. Berlin: Springer, pp. 26-51.

Hagemann, Harald and Peter Kalmbach, eds. 1983. Technischer Fortschritt und Arbeitslosigkeit. Frankfurt am Main: Campus Verlag.

Hagemann, Harald and Claus-Dieter Krohn, eds. 1999. Biographisches Handbuch der deutschsprachigen wirtschaftswissenschaftlichen Emigration nach 1933. München: Saur.

Hicks, John R. 1965. Capital and Growth. Oxford: Clarendon Press.

- 1973. Capital and Time. Oxford: Clarendon Press.

Janssen, Hauke. 1998. Nationalökonomie und Nationalsozialismus: die deutsche Volkswirtschaftslehre in den dreissiger Jahren. Marburg: Metropolis.

James, Harold. 1986. The German Slump. Oxford: Oxford University Press.

Kaldor, Nicholas. 1932. “A case against technical progress?” Economica 36 (May): 180-96.

Krohn, Claus Dieter. 1993. Intellectuals in exile: Refugee scholars and the New School for Social Research. Amherst: University of Massachusetts Press. Translated by Rita and Robert Kimber 
from the German Wissenschaft im Exil. Deutsche Sozial- und Wirtschaftswissenschaftler in den USA und die New School for Social Research. Frankfurt and New York: Campus, 1987.

Kruse, Alfred. 1959. Geschichte der volkswirtschaftlichen Theorien, 4th edition. Berlin: Duncker \& Humblot.

Lasker, Bruno, Hans Staudinger, and Albert Salomon. 1940. "Emil Lederer, 1882-1939. I: The Sociologist." Social Research 7 (3): 337-58.

Lederer, Emil. 1925. "Konjunktur und Krisen." In Grundriss der Sozialökonomik. Tübingen: J.C.B. Mohr, pp. 354-413.

—. 1927. "Monopole und Konjunktur." In Vierteljahreshefte zur Konjunkturforschung I Ergänzungsband 2: 13-32.

—. 1931a. Aufriss der ökonomischen Theorie. Dritte erweiterte und völlig umgearbeitete Auflage der Grundzüge der ökonomischen Theorie. Tübingen: Verlag J.C.B. Mohr. - 1931b. Technischer Fortschritt und Arbeitslosigkeit. Tübingen: J.C.B. Mohr.

1931c. Wirkungen des Lohnabbaus. Ein Vortrag. Tübingen: J.C.B. Mohr.

1932. Planwirtschaft. Tübingen.

1933. "Technical Progress and Unemployment." International Labour Review 28 (1): 1-25.

_ 1934. "Technology." In Edwin R. A. Seligman and Alvin S. Johnson, eds., Encyclopedia of the Social Sciences, Vol. 14. New York: Macmillan, pp. 553-60.

- 1938. Technical Progress and Unemployment: An Enquiry into the Obstacles to Economic Expansion. Geneva: International Labour Office.

Löwe, Adolf. 1933. Contribution to Der Stand und die nächste Zukunft der Konjunkturforschung. Festschrift für Arthur Spiethoff. München: Duncker \& Humblot, pp. 154-60.

Marschak, Jakob, Alfred Kähler, and Eduard Heimann. 1941. "Emil Lederer, 1882-1939. II: The Economist." Social Research 6: 79-105.

Mehrling, Perry G. 1997. The Money Interest and the Public Interest: American Monetary Thought, 1920-1970. Cambridge, MA: Harvard University Press.

Mongiovi, Gary. 1997. "Émigré Economists at the New School, 1933-1945." In Harald Hagemann, ed., Zur deutschsprachigen wirtschaftswissenschaftlichen Emigration nach 1933. Marburg: Metropolis Verlag, pp. 383-402.

Pribram, Karl. 1981. A History of Economic Reasoning. Baltimore and London: The Johns Hopkins University Press.

Schumpeter, Joseph A. 1954. History of Economic Analysis. New York: Oxford University Press.

Tugan-Baranovsky, Michael von. 1901. Studien zur Theorie und Geschichte der Handelskrisen in England. Jena: Verlag von Gustav Fischer. Originally published in Russian in 1894. The German translation is from the second Russian edition of 1900 (the name is spelled Tugan-Baranowsky in this edition, here the spelling has been adjusted to the prevailing usage). 